\title{
INDIAN BUSINESS MANAGERS PERCEPTIONS OF ORGANIZATIONAL VALUES, ETHICS AND SUCCESS
}

\begin{abstract}
The purpose of this paper is to investigate Indian business manager's perceptions of organizational values and their assessment of the relationship between ethical actions and success. The findings indicate that most Indian managers feel that they work for organizations with strong values, however, a significant number of those managers also felt that unethical behavior helps one to succeed. In addition, we found that neither the size of the firm nor whether the company was public or private, had an effect on perceptions of organizational values or feelings about the relationship between ethics and success. Overall, this research provides some new and unexplored insights as to the role ethics play in an Indian manager's assessment of their organization, their personal feelings about ethics and professional achievement. and how these ethical perceptions compare with managers in businesses in China.
\end{abstract}

Keywords: Business managers, India, Etbics, Organizational values, Success

Satish Deshpande

Western Michigan University

Johanan Collins

Western Michigan University

JoAnn Atkins

Western Michigan University

Stephen Newell

Western Michigan University

Correspondence: Stephen Newell

Haworth College of Business, Western Michigan University

steve.newell@wmich.edu 


\section{INTRODUCTION}

Businesses are being challenged by an increasingly open and competitive market place with complex social changes that have led to "new, values, practices and expectations" about the way organizations operate internationally (Fontrodona, Ricart, and Berrone 2018, p.887). Consequently, understanding ethics has become an indispensable requirement for doing business in the international marketplace (Christie, Kwon, Stoeberl, and Baumhart 2003, Seshadri, Raghavan, and Hegde 2007, LeFebvre 2011) and is considered necessary when developing productive relationships (Hoff and Pandey 2005, Raja and Kumar 2008, Tsalikis, Seaton, and Li 2008). Research reveals that in order to effectively do their job, an executive must understand and comprehend differing cultural values and ethical standards across the globe (Ferrell, 2005). However, the assumption that Western moral standards are generally accepted and applied to all non-Western countries in their business dealings is false (Oumlil and Balloun 2009, Robertson, Crittenden, Brady and James 2002, Tsalikis and Lassar 2009). Religious and cultural differences between countries and regions impact ethical standards and thus affect business associations (Ruhe, 2008). Some examples of these cultural norms that have influenced business practices include "Guanxi" (connections or networks) in China, "Blat" (informal agreements) in Russia, and "Jugaad" (quick fix) in India.

It should be noted that the overall moral attitudes of individuals and organizations is a function of culture (Paik, Lee and Yong 2019). As businesses continue to expand throughout the globe, trade and social norms will frame many of these relationships. Consequently, for organizations to be successful, they need to comprehend not only the ethical standards of the country they are doing business in, but also understand the background from which they developed (Berger and Herstein, 2012).

Relatedly, a number of studies have examined the ethical framework of doing business across countries and cultures. For example, the ethical attitudes of executives were investigated in the United Kingdom (Diacon and Ennew 1996). In another study, the ethical differences between managers in Morocco and the United States were analyzed (Oumlil and Balloun, 2009). Valentine (2004) researched the distinctions in ethical evaluations amongst Spanish and American business professionals. Carroll (1997) who conducted another 
inquiry in this area, compared ethical systems for businesses in Japan and the US. Sims (2004) examined attitudes towards business ethics in America, Israel, Australia, South Africa and Turkey. Erondu (2004) researched corporate ethics in Nigeria. Another investigation compared ethical decision-making and philosophies between mangers in Korea and the United States (Paik, Lee, and Yong, 2019). One study surveyed top executives from Australia, Canada, and Sweden on their organization's code of ethics and what specific content initiatives in the code were most effective in promoting ethical practices (Singh, Wood, Callaghan, Svensson, and Anderson, 2018). In a related study in Brazil, researchers analyzed whether the make-up of the board of directors affected the firm's code of business ethics (Correia and Lucena, 2020).

In this paper, we focus on gaining a better grasp of business in India and the role ethics plays in the minds of managers. Specifically, we investigate for the first time whether size and status (public vs. private) of Indian companies play a role in a manager's ethical perceptions. In addition, we analyze possible differences between Chinese and Indian manager's views on organizational values and the relationship between ethics and success.

\section{LITERATURE REVIEW}

\section{History of business ethics in India}

In their in-depth article on the evolution of business ethics in India, Berger and Herstein (2014) suggest that India underwent five historical eras or "rajs" in its ethical development. These include: 1) Panchayat Raj; 2) British Raj; 3) License Raj; 4) Invisible Raj; and 5) Jugaad Raj. The first era, the Panchayat R $a j$, ran from ancient Vedantic times to just before the British took over India. The Panchayati, a group of elders in the community that were chosen to regulate the community, were the primary legal and ethical cultural ruling apparatus during this time period (Rajeev, 2007). The panchayat structure emphasized high business morals while encouraging wealth creation (Kanagasabapathi, 2007).

The next era, the British Raj, lasted from about 1858 to 1947. This phase furthered India's integration into the global economy via the British Empire. This relationship was enhanced during the World Wars when hostilities affected business relationships between 
Britain and its colonies in the Orient. A shortage of products led to an increased demand for a wide array of goods from India (Kanagasabapathi, 2007). Newer ethical systems due to British colonial rule (based on Greco-Roman practices) replaced the traditional Vedantic customs. These new moral principles caused the decline of the old ethical systems, bringing about a modification of acceptable ethical conduct in India (Chakraborty, 1997; Majumdar, 2004).

The third phase in the evolution of ethics in India is known as the License Raj, which occurred roughly from 1947 to 1990 and corresponds to the time in which India became independent. During this period, India's elected leaders established a mixed economic style, fashioned in a combination of a Soviet-like command economy with elements of the free market. This new mixed economic and administrative structure was implemented over the traditional Hindu Vedantic-based system that had been in place for most of India's history. These changes meant that most major investments and businesses were controlled by the government (Kanagasabapathi, 2007). Minor investments were successfully handled by private organizations (Fikkert and Rana, 1998). Inefficiency, over reliance on government, and unethical behavior by politicians and managers in state-owned companies, resulted in a largely corrupt and wasteful system of commerce.

The next phase is known as the Invisible Raj which lasted for about five years from 1990 to 1995. Ethical standards were further modified under the pressures of powerful global markets (Kanagasabapathi, 2007). The International Monetary Fund (IMF) and the World Trade Organization (WTO) demanded that the government privatize many state agencies and lower its involvement in Indian businesses. The focus on profits, may have helped to justify many unethical business practices.

The most recent era is the Jugaad Raj, which began in 1995 and continues until the present. Within this era, the practice of "Jugaad" has been prevalent (Birtchell, 2011). "Jugaad" is a Hindi word referring to a beneficial trait of resourcefulness when the odds are against you. "Jugaad," is a person that is highly resourceful and networked who can get things done by weaving his or her way through (or around) the system (Birtchell, 2011; Krishna, 2003). Jugaad has evolved into a slang for a "quick fix." It has been argued that the opening up of international markets, the desire for wealth, and the envy of Chinese 
global economic success has negatively impacted business ethics in India (Saran and Guo, 2005).

Overt corruption in India is slowly fading due in part to the 2013 Lokpal and Lokayuktas Act, an anti-corruption law that establishes a process to investigate public officials who may have engaged in ethical wrong-doing. In addition, in 2018 the Government of India made amendments to the 'Prevention of Corruption Act, 1988 which now includes the criminalizing of the act of giving or taking a bribe. Also, the importance of grassroot movements among the people to fight dishonesty is another way in which positive change has been affected. Ultimately, modifying ethical standards in business and government is often achieved politically through free and open elections (Riley and Roy, 2016). Furthermore, second and third generation business people (who are often educated at western universities) are currently taking on more leadership (and sometimes ownership) roles in Indian companies.

Consequently, principled organizational procedures are being introduced and implemented in a growing number of organizations across India. However, though there are noticeable improvements, unethical business practices are still a significant problem both in the public (government) and in private industries.

\section{Ethics government (public)}

In India, the term "Jugaad" refers to the practice which enables businessmen to find "interesting" ways around government red tape. Corruption in India is one of the worst problems faced by its citizens. It is estimated that over $50 \%$ of public works contract are obtained by paying bribes (Davis, 2004). Bussel (2010) states that Indians paid over USD $\$ 5$ billion per year in petty corruption. Dishonesty in the Indian Government was studied by Vaidya (2019). Specifically, he took a deep look at governmental organizations in India and found that the structure of corruption in India is highly organized and systematic.

Crime and corruption seem to have upended societal moral and ethical barriers and negatively affected the economy (Chakraborty, 1997; Khandwalla, 2002; Das, 2006). Corruption in India has seeped into all levels of society, from senior government 
bureaucrats and politicians to high ranking public servants to professional businessmen, office clerks and even common street vendors (Agarwala, 2001). Currently India's justice system appears to serve political rather than public interests (Berg and Holtbrugge, 2001; Bhasin, 2010). If politicians and bureaucrats themselves are unethical, they will be hesitant to clean up corruption regarding either their own actions or those of their subordinates (Chakraborty, 1995).

Overall, governmental activities seem to be significantly impacted by officials who are corrupt. The National Social Responsibility Index (NSRI) is a tool that has been used to measure the extent to which a government treats its citizens fairly. The results of surveys that measure the NSRI, suggest that citizens still see themselves as being treated unethically by India's governmental institutions (Heston and Kumar, 2008; Tsaalikis, Seaton, and Li, 2008; Vernon, Williams, Corbridge, and Srivastava, 2006).

\section{Ethics organizations (private)}

Business practices in many private organizations are also seen to be ethically lacking (Vernon, Williams, Corbridge, and Srivastava, 2006; Heston and Kumar, 2008). Specifically, when business practices in India are studied, dishonesty ranks high in the list of concerns by the public. Overall, research suggests that Indian companies seem to keep to a lower standard of business ethics in their organizations than companies in the West (Biswas, 1998; Kanagasabapathi, 2007).

The 2019 India Corruption Survey reported that fifty-one percent of those responding to their questionnaire stated that they had paid money to entice a government official (Local Circles, 2019). In another study, of those Indians who had accessed public services, seven out of 10 Indians had made bribe payment, versus only 0.2 percent of those surveyed in Japan (the least corrupt nation) (Venkataraman, 2018).

Ramesh (2014) states that bribery and corruption are the biggest ethical ills that face Indian companies. The consumers have a poor perception of ethical practices in private companies. He concluded that the public perceives that Indian businesses are less ethical compared to 10 years prior to the paper's publication. The Indian public also believes that an ethical company is at a disadvantage in the current corrupt business environment. Indians 
believe that bribery, corruption, safety, and security in the workplace are the most serious ethical issues that need to be addressed (Mulla 2003).

Another issue is the perception of the ethical behaviors of managers. Rooplekha (2004) studied 340 middle level managers from public and private companies in India who rated their superiors on 22 ethical leadership items. Interestingly, superiors rated themselves as more ethical than their subordinates rated them. In addition, managers in private companies were rated as more ethical than those in the government positions.

Brown (2006) studied the issue of corporate integrity and approached it from a civic perspective, the study assumed that corporations are members of civil society, and corporate members are seen as citizens, and corporate decisions are guided by civic norms. The study found that integrity in the organization must be embedded into the communication patterns and interpersonal relationships at work, which then results in civic norms and ethical behaviors by the corporation and its workers. The study also found that integrity was influenced by the value orientation and compliance orientation among the employees.

The study of ethics in an Indian business context is important. Ethical constructs and relationships that apply to the Western world and the United States cannot be assumed to be directly applicable in India. Specifically, by better understanding the unique cultural context of the ethical perceptions of business managers in India, companies from other nations will have a better understanding of how navigate commercial trade with one of the largest markets in the world.

\section{HYPOTHESES}

\section{Public and private company ethics}

There has been limited research that suggests managers in private companies are more ethical than those in public companies. In one study that surveyed individuals in public and private organizations in Sweden, the results indicated that private sector companies tend to be more engaged with ethics than public organizations (Svensson, Wood, and Callaghan, 
2009). Hawkins et al. (2011) surveyed individuals with buying responsibilities and found that those who worked at private companies behaved less opportunistically and also were more likely to have a specific policy that prohibited deceiving suppliers, than those from public organizations. In another study, managers of private firms reported higher corporate ethical values and exhibited greater ethical intentions than managers working for public institutions (Sardzoska and Tang, 2009). Khuntia and Suar (2004) reported that subordinates in private firms perceived their managers to be more ethical than those similar employees in public organizations in research conducted in India. Overall, the few studies that have been undertaken comparing ethics in public versus private organizations suggest that ethical differences may be present. Thus, it is hypothesized that:

Hypothesis 1a: There will be a significant difference in perceptions of the values of their organization between Indian managers in private companies and managers in public companies.

Hypothesis 1b: Indian managers in private companies will perceive a more positive and significant connection between ethics and success than managers employed in public companies.

\section{Ethics in relation to size of company}

There has been limited research on whether an individual's ethical perception has any relation to the size of the organization that they work for. One study suggested that those employed in larger organizations have stronger ethical predispositions (Schminke, 2001). In other research, the authors reported that small business managers/owners responded less ethically to a hypothetical business scenario than managers/owners in larger companies in a study conducted in 1993 (though no differences were found for similar research conducted in 1985 and 2001) (Longenecker, Moore, Petty, Palich, and McKinney, 2006). Another study that looked at Italian companies, found that larger organizations have ethical codes of conduct that are of higher quality than those in smaller firms (Garegnani, Merlotti, and Russo, 2015). There has been no research based in India that has specifically looked at whether the size of the organization plays a role in ethical perceptions of its managers. The limited academic research suggests differences in organizational ethics between large and small firms, thus, we hypothesize that: 
Hypothesis 2a: There will be a significant difference in perceptions of the values of their organization between Indian managers in smaller companies and managers in larger companies.

Hypothesis 2b: There will be a significant difference in perceptions of the connection between ethics and success for Indian managers employed in smaller companies versus those in larger companies.

\section{Organizational ethics in China vs India}

According to Xiaobo (2016), China has been evolving in terms of their ethical business practice by merging modern Western economic thought with their own unique commercial practices within the framework of Confucianism. This transition has not been smooth and he believes that there are two major reasons. First, he posits that traditional Chinese political thought had "contempt for economic activity" and those involved in business have "been treated with disdain" for their trade. The second relates to the fact that up until the 1980's when Deng Xiaoping began to open up reforms, there was little continuity in business policy as it relates to ethical norms and practices. Chinese business practices are largely grounded in cultural values such as collectivism and paternalism, in which managers and employees use situational and particularistic criteria to respond to ethical situations rather than universally accepted norms (Archichvili, Jondle, Kowske, Cornachione, Li, and Thakadipuram, 2012). Specifically, the still common practice of Guanxi (in which personal connections and social networks unfairly influence outcomes both within and outside an organization), may impact the way in which rules and professional standards are perceived by managers as practiced by their companies (Desphande, Joseph, and Shu 2011; Newell, Wu, Leingpibhul, and Jiang 2016).

In a study investigating the ethical climate of organizations in China (Deshpande, Joseph, and Shu, 2011), it was reported that most managers felt that the work climate was driven by rules and standards of professionalism. A minority of managers indicated that the company was guided by the consideration of their employee's collective interests. For those Chinese managers who believed their organization was "rules-based" there was a significant link between ethical behavior and success. Contrastingly, managers in other types of organizations (those that emphasized professionalism and caring) did not indicate a 
significant connection between ethics and career achievement. In another study that compared ethical cultures in China with those in Brazil, Russia, U.S. and India, it was found that managers and employees from China and Russia had significantly lower perceptions of organizational ethics than those did in the U.S., Brazil and India (Archichvili, Jondle, Kowske, Cornachione, Li, and Thakadipuram, 2012). Overall, past research seems to indicate that managers in organizations in China have different ethical perceptions than those in India. Thus, it is hypothesized that:

Hypothesis 3a: Indian Managers have significantly different views on their organizational values than do Chinese Managers.

Hypothesis 3b: Indian managers will perceive a more positive and significant connection in the relationship between ethics and success than Chinese managers.

\section{METHOD}

\section{Sample}

The respondents of this study consisted of Indian business managers who have purchasing responsibilities. A total of 181 individuals completed the survey. We recruited subjects from a number of large companies in India and through national purchasing and other trade organizations. The questionnaire was distributed on-line and gathered over approximately four months. The results indicated that eighty-one percent of the respondents were employed at private companies, while the remaining eighteen percent were working at public organizations. Thirty-seven percent indicated that they were from small companies, $29 \%$ were from medium-sized firms and 34\% from large businesses. The average number of years of purchasing experience was 12 , ranging from less than a year to over 30 . Males consisted of $93 \%$ of those surveyed, while only $7 \%$ were female.

The additional data used to test Hypotheses $3 \mathrm{a}$ and $3 \mathrm{~b}$ was obtained from the authors of a previous study which consisted of 45 Chinese business managers from the Zhejiang province on the central coast of China (Deshpande, Joseph, and Shu, 2011). The data was originally collected via personal interviews. 
T-tests and ANOVA's were used to determine the hypotheses. T-tests are the most appropriate method in which to determine whether two groups are statistically different from one another. ANOVA was used to test whether there were significant the differences in means between small, medium and large companies.

\section{RESULTS}

\section{Organizational values}

The measure for organization values consisted of three questions, all taken from previous research (Deshpande, George, and Joseph, 2000). These items consisted of professionalism (employees comply with professional standards), caring (consideration for others wellbeing), and rules (everyone needs to follow regulations of the organization) using Likertscale measures anchored by Strongly Disagree (1) and Strongly Agree (5). The items loaded on one factor with a Chronbach's alpha of .725, which is within the acceptable threshold suggested by Cortina 1993 (see Table 1) and all three were significantly correlated with each other (see Table 2). In relation to organizational values, the results of the current research found eighty-one percent of the respondents agreed that people in their firms are expected to follow legal and professional standards, with only six percent disagreeing (12\% indicated "neutral" - neither agreeing or disagreeing with the statement). In addition, 75\% agreed that an important organizational consideration is determining what is best for everyone with $8 \%$ disagreeing. Finally, eighty-eight percent felt that it was important to follow rules and procedures in their organization with only $3 \%$ disagreeing (see Table 3 ).

Table 1. Factor analysis of organizational values

\begin{tabular}{lc}
\hline \multicolumn{1}{c}{ Items } & Loadings \\
\hline $\begin{array}{l}\text { 1. People are expected to comply with the law and professional standards in my } \\
\text { organization* }\end{array}$ & 0.68 \\
2. Our major consideration is what is best for everyone in this organization* & 0.68 \\
3. It is important to follow rules and procedures in this organization* & 0.71 \\
\hline 65 & Journal of International Business and Economy
\end{tabular}




\begin{tabular}{|c|c|c|c|}
\hline *A five-po & $\begin{array}{r}\text { Vari } \\
\text { Cc } \\
\text {-scale was used } \\
\end{array}$ & $\begin{array}{l}5 \\
47.7 \% \\
0.73 \\
\text { gree, } 3=\end{array}$ & agree) \\
\hline \multicolumn{4}{|c|}{ Table 2. Organizational values } \\
\hline Value & Professionalism & Caring & Rules \\
\hline Professionalism & 1.00 & - & - \\
\hline Caring & $0.46^{* *}$ & 1.00 & - \\
\hline Rules & $0.49 * *$ & $0.48^{* *}$ & 1.00 \\
\hline $0.01(2$ tailed $)$ & & & \\
\hline
\end{tabular}

Table 3. Organizational values results

\begin{tabular}{cccccc}
\hline Value & \% Disagree & \% Neutral & \% Agree & Mean & $\begin{array}{c}\text { Standard } \\
\text { deviation }\end{array}$ \\
\hline Professionalism* & 6.1 & 12.0 & 81.8 & 4.39 & 1.02 \\
Caring* & 7.7 & 17.7 & 74.6 & 4.07 & 1.04 \\
Rules* & 3.3 & 8.3 & 88.4 & 4.44 & .83
\end{tabular}

* A five-point Likert-scale was used $(1=$ Strongly disagree, $3=$ Neutral, $5=$ Strongly agree $)$.

\section{Ethics and success}

The measures for ethics and success consisted of five statements which were anchored by strongly disagree (1) to strongly agree (5) (Deshpande, George, and Joseph, 2000). The items consisted of statements about the relationship between success and ethical standards/actions. The items loaded on one factor with a Chronbach's alpha of .87 (see Table 4), which is within the acceptable threshold (Cortina 1993). It should be noted that the questions were worded in a way that if one agrees with the statements, he or she feels that being unethical helps someone to succeed. In general, the vast majority of those surveyed felt that unethical behavior did not drive success. In every question, except question 2, more than fifty percent of the respondents felt unethical behavior did not lead to success (see Table 5). In addition, a single question was also asked to test general feelings 
about whether successful managers are more ethical, 51\% agree while 17\% disagreed with a mean of 3.59 (see Table 6).

It should be noted that in terms of ethical behavior and success, the analysis indicates that about half of Indian managers responded that unethical behavior did not help to drive success. Conversely, approximately one quarter of those surveyed felt that unethical behavior did help one to be successful. The other $25 \%$ neither agreed nor disagreed that these unprincipled behaviors affected success.

Table 4. Factor analysis of ethics and success

\begin{tabular}{|c|c|}
\hline Items & Loadings \\
\hline & 0.61 \\
\hline 1. In order to succeed at work, it is necessary to compromise one's ethics* & \\
\hline 2. Successful managers withhold information that is detrimental to their self-inter & 0.70 \\
\hline 3. Successful managers make rivals look bad in the eyes of others* & 0.80 \\
\hline $\begin{array}{l}\text { 4. Successful managers look for a "scapegoat/Bakra" when they feel they may be } \\
\text { associated with failure* }\end{array}$ & 0.81 \\
\hline 5. Successful managers take credit for the ideas and accomplishments of others* & 0.84 \\
\hline \multicolumn{2}{|c|}{$\begin{array}{l}\text { * A five-point Likert-scale was used }(1=\text { Strongly disagree, } 3=\text { Neutral, } 5=\text { Strongly agree }) \text {. } \\
\text { Eigen value }-3.26 \\
\text { Variance explained }-65.2 \% \\
\text { Coefficient alpha }-0.87\end{array}$} \\
\hline
\end{tabular}

Table 5. Ethics and success results

\begin{tabular}{|c|c|c|c|c|c|}
\hline Item \# & $\begin{array}{l}\% \\
\text { Disagree }\end{array}$ & $\%$ Neutral & \% Agree & Mean & $\begin{array}{l}\text { Standard } \\
\text { deviation }\end{array}$ \\
\hline 1 & 63.0 & 17.7 & 19.3 & 2.14 & 1.33 \\
\hline 2 & 38.7 & 34.3 & 27.0 & 2.77 & 1.27 \\
\hline 3 & 54.1 & 23.8 & 22.1 & 2.41 & 1.27 \\
\hline 4 & 51.4 & 21.5 & 27.0 & 2.51 & 1.38 \\
\hline 5 & 50.3 & 20.4 & 29.3 & 2.55 & 1.40 \\
\hline
\end{tabular}


Table 6. Ethics and successful managers

\begin{tabular}{llllll}
\hline Measure & $\begin{array}{l}\text { \% } \\
\text { Disagree }\end{array}$ & \% Neutral & \% Agree & Mean & $\begin{array}{l}\text { Standard } \\
\text { deviation }\end{array}$ \\
\hline $\begin{array}{l}\text { Successful managers are } \\
\text { generally more ethical } \\
\text { than unsuccessful } \\
\text { managers* }\end{array}$ & 3.3 & 8.3 & 88.4 & 4.44 & .83 \\
$*$ A five-point Likert-scale was used $(1=$ Strongly disagree, $3=$ Neutral, $5=$ Strongly agree $)$. & \\
\end{tabular}

\section{Ethical perceptions in public vs. private organizations}

There has been research that suggests managers in private companies are more ethical than those in public companies (Khuntia and Suar, 2004). Consequently, we tested whether those individuals working for private companies had a different view of organizational values than those working for public companies. The findings of the current study found no significant differences between managers working for public and private companies in their perceptions of organizational values $(t=1.4, p=0.23)$. In addition, for Hypotheses $1 b$, managers in private companies did not indicate a significantly more positive connection between ethics and success than managers in public companies $(\mathrm{t}=-0.9, \mathrm{p}=0.46)$. Consequently, both Hypotheses $1 \mathrm{a}$ and $1 \mathrm{~b}$ are rejected.

\section{Ethics and the size of an organization}

There has been limited research on whether an individual's ethical perception has any relation to the size of the organization that they work for. One study suggested that those employed in larger organizations have stronger ethical predispositions (Schminke, 2001). In response, we tested whether the size of the company that respondents worked for affected perceptions of organizational values. Contrary to the findings by (Schminke, 2001), our study uncovered no significant differences between small, medium, and large company managers in their perceptions of organizational values $(\mathrm{F}=.074, \mathrm{p}=0.48)$. We also investigated whether there were any differences in size of firm and mangers appraisal of ethics and success. The results suggest that managers from larger firms do not have significantly different perceptions about the association between ethics and success than those from smaller companies $(\mathrm{F}=0.24, \mathrm{p}=0.79)$. Thus, Hypotheses $2 \mathrm{a}$ and $2 \mathrm{~b}$ are rejected. 


\section{Organizational ethics in China vs. India}

To test hypothesis $3 \mathrm{a}$ and $3 \mathrm{~b}$, we utilized data from a previous study that asked Chinese managers the same questions about value perceptions of their organization and the relationship between ethics and success (Deshpande, Joseph, and Shu, 2011). We compared the results between that research and the current study on Indian managers. The findings indicated that Chinese managers rated their firms significantly lower than Indian managers on professionalism (mean 3.87 vs. $4.39, \mathrm{p}<.05$ ), caring (mean 3.27 vs. $4.07, \mathrm{p}<.01$ ), and rules $(3.89$ vs. $4.44, \mathrm{p}<.01)$. Thus, Hypothesis $3 \mathrm{a}$ is supported (see Table 7 ).

Table 7. Organizational values: China vs. India

\begin{tabular}{|c|c|c|c|c|c|}
\hline \multirow[t]{2}{*}{ Item } & \multicolumn{2}{|c|}{ China $(n=45)$} & \multicolumn{2}{|c|}{ India $(n=181)$} & \multirow[b]{2}{*}{$\underline{\text { T-test }}$} \\
\hline & $\underline{\text { Mean }}$ & $\underline{\text { Std. Dev. }}$ & Mean & $\underline{\text { Std. Dev }}$ & \\
\hline Professionalism* & 3.87 & 1.49 & 4.39 & 1.02 & $2.20^{*}$ \\
\hline Caring* & 3.27 & 1.16 & 4.07 & 1.04 & $4.51 * *$ \\
\hline Rules* & 3.89 & 1.17 & 4.44 & .083 & $2.97 * *$ \\
\hline \multicolumn{6}{|c|}{${ }^{*} \mathrm{p}<0.05$ (2-tailed) ${ }^{* *} \mathrm{p}<0.01$ (2-tailed) } \\
\hline
\end{tabular}

Hypothesis $3 \mathrm{~b}$ posits that managers in India would perceive a significantly different and more positive view on the connection between success and ethics than Chinese managers. Though Indian mangers expressed a more positive view on the association between ethics and success, the difference was not statistically significant (see Table 8). As a result, Hypothesis $3 \mathrm{~b}$ is rejected. 
Table 8. Ethics and success: China vs. India

\begin{tabular}{llllll}
\hline Measure & \multicolumn{1}{c}{ China $(\mathbf{n}-45)$} & India $(\mathbf{n}=181)$ & & \\
\hline & Mean & Std. Deviation & Mean & Std. Deviation & T-test \\
$\begin{array}{l}\text { Successful } \\
\text { managers are } \\
\text { generally more }\end{array}$ & 3.87 & 1.49 & 4.39 & 1.02 & .40 \\
$\begin{array}{l}\text { ethical than } \\
\text { unsuccessful } \\
\text { managers }\end{array}$ & & & & & (not significant) \\
\hline
\end{tabular}

\section{DISCUSSION AND IMPLICATIONS}

India is currently the world's sixth largest economy in terms of GDP, overtaking the UK and France, and is the fastest growing trillion-dollar nation (Silver, 2020). Exports to India from the U.S. were $\$ 58.6$ billion in 2019, up 3.3\% from 2018 (Office of the United States Trade Representative 2020). Overall, India is a major economic force and an increasing number of international organizations are investing in the country. Thus, it is important for firms who want to successfully conduct business in India to better understand Indian manager's positions on a variety of issues including values and ethics.

The findings indicate that most managers feel that they work for a company with strong values. The vast majority of those surveyed agreed that their organization fulfilled the values of professionalism (82\%), caring (75\%), and rules (88\%). Less than ten percent disagreed with each of these statements. Thus, it seems that a significant number of managers feel that their firm has professional standards that employees are expected to follow. Whether these expectations are formalized and whether most individuals in the organization follow them is a question for future research.

There were no significant differences in organizational values between public and private companies. Also, no significant contrasts in these measure between employees in small, medium, or large firms were found. The current study did not reveal any significant differences in the measure for ethics and success between public and private companies. Also, there were no significant distinctions between employees in small, medium or large firms and their relationship between success and ethical behavior were present. 
In general, the results of the study indicate that Indian organizations have a set of values in place that provide a solid foundation for global business dealings. Consequently, companies from other nations who want to do business in India should feel confident that most organizations have a solid set of rules and professional standards that provide a stable and ethical environment with which to work.

Of some concern is the finding that approximately twenty-five percent of managers feel that unethical behavior helps to achieve success (and another twenty-five percent neither agrees nor disagrees with this sentiment). This may be a manifestation of the general distrust that the citizens of India have with both government and private organizations. This result seems to suggest that there is a need for education and/or training on ethical issues at both public and private organizations.

According to Seshadri et al. (2007), there are a number of actions that Indian companies need to take to develop an ethical corporate mentality. First, they need to develop a well-defined code of principles that can be effectively implemented within the company. In addition, these standards must be communicated to employees, customers and other stakeholders. At the same time, training programs must be developed in which employees not only understand the ethical rules of the organization, but they must also be educated on how these guidelines apply to individuals in their position and further, provide appropriate responses to specific ethical scenarios that they may face. There also must be a structured process for reporting ethical issues and a procedure for adjudicating any violations. Finally, these codes of conduct must be regularly reviewed and modified, when necessary, to meet the changing needs of the organization and society. Overall, ethical training is a prerequisite to developing an effective organizational ethical culture (Remisova, Lasakaova, and Kirchmayer, 2019).

Often the first step is for a company to evaluate the current moral climate of their firm. These assessments may lead to developing official ethical standards for the organization that includes employee training and a formal process to handle infractions in fair and judicial manner. In addition, they may need to modify their current hiring practices in order to implement strategies that screen out candidates who are unlikely to positively 
contribute to the ethical climate of the company. Specifically, the process of establishing and maintenance of an ethical organization becomes much easier if the company actively recruits employees who reflect the company's principled standards. Ritterbush (2020) provides some key strategies in hiring ethical employees. She explains that the first step is to ensure that the company has truly created an ethical culture (Seshadri, Raghavan, and Hegde, 2007). Next, she argues the need to make sure all of those who are inclined to apply for employment understand the importance of ethics to the organization. This point-ofview should be clearly presented in the job description, emphasized in the company web site, and reiterated in other promotional information about the firm. These declarations become an important initial screening device in dissuading certain individuals from applying. After narrowing down the number of candidates using appropriate background and reference checks, the interview process may include ethical behavioral questioning, integrity assessments, and/or personality tests to provide more information as to the honesty and moral make-up of the individual.

The current study also provides some initial insights as to the similarities and differences between Indian and Chinese managers and their perceptions of ethics. Though there were no differences among managing groups in their perceived relationship between success and ethics, the results revealed significant distinctions between the Chinese and Indian managers in their opinions on organizational values. In all three dimensions tested, managers from China rated their organizations significantly lower than those in similar positions from India. Specifically, the results indicated that Chinese managers felt their organizations were less rule-based and professional than their Indian counterparts. Comparing the two countries in Hofsted's cultural factors, India is rated significantly higher than China on the uncertainty avoidance dimension (Hur, Kang, and Kim, 2015). This can be broadly defined as the extent to which one feels threatened by uncertain situations. Having a strong set of rules and professional standards would be a way an organization creates stability to the relatively ambiguous and chaotic environment that engulfs much of Indian life.

Recent changes in law, attitudes and business practice seem to have had a positive effect on corruption in the country. A November 2020 TRACE International report (2020) 
put India at the $77^{\text {th }}$ position on a global list for business bribery, which is a large improvement from 185/197 it had in 2014. The State Bank of India's Ecowrap publication's cross-country analysis between 2012 and 2018 indicated that for India, UK, Greece, Egypt, and Italy an increase in GDP was correlated with a reduction in their score on the Corruption Perception Index (CPI) (published by Transparency International). During this six-year period, India climbed in the country rankings from $94^{\text {th }}$ to $78^{\text {th }}$ in the CPI (Ghosh, 2021). Overall, this ethical evolution that is going on in India is similar to that which has happened in other developing countries like South Korea, Singapore, and Taiwan.

Overall, this research provides an important and current insight of attitudes and perceptions of organizational ethics and the role it has in defining success with Indian managers. In addition, for the first time, this study explores whether one's ethical perceptions are impacted by the status (public vs. private) and/or the size of the company in which Indian managers work. Finally, utilizing data from a previous study, we explore potential differences between Indian and Chinese managers and their assessment of ethics and success and organizational values.

\section{LIMITATIONS AND FUTURE RESEARCH}

The current research has a number of limitations. This study concentrated on managers with purchasing responsibilities. It is not clear if these results can be expanded to other professionals in India or elsewhere, thus, subsequent research should consider sampling managers with broader responsibilities and expand the number of those surveyed in order to increase generalizability of the findings. In addition, only $7 \%$ of our respondents were women. India currently does not have a good representation of women in managerial roles. Specifically, one 2019 study indicated that women held $8 \%$ of total management positions in India (Kersley, Klerk, Boussie, Longworth, Natzkoff, and Ramji, 2019). Future research should focus on female managers to better understand their perspectives on ethics. Also, we used an online questionnaire to collect the data which may result in same source bias. The study uses a quantitative approach. Consequently, studies in the future may want to utilize more qualitative methods to provide a deeper understanding of the ethical thinking 
of those sampled. Finally, it should also be noted that there are a small number of journal articles that have examined issues surrounding Indian managers and business ethics. Even fewer studies have addressed whether size or status of the company were related to the ethical viewpoints of employees who work at a company. As a result, the hypotheses in the current study were based on limited academic inquiries into these areas. The current results will provide future investigators with additional data with which to posit their related hypotheses and ultimately refine the existing knowledge of this important area of research.

\section{REFERENCES}

Agarwala, P. N. 2001. A Comprehensive History of Business in India - from 3000 B.C. to 2000 A.D. Tata McGraw-Hill Pub. Co. New Delhi: New York.

Archichvili, A. D. Jondle, B. Kowske, E. Cornachione, J. Li, and T. Thakadipuram. 2012. Ethical cultures in large business organizations in Brazil, Russia, India and China. Journal of Business Ethics 30 (105): 105-119.

Berg, N. and D. Holtbrugge. 2001. Public affairs management activities of German multinational corporations in India. Journal of Business Ethics 30 (1): 415-428.

Berger, R. and R. Herstein. 2012. The limits of Guanxi from the perspective of the Israeli diamond industry. Journal of Chinese Economic and Foreign Trade Studies 5 (1): 29-41.

Bhasin, M. 2010. Dharma, corporate governance and transparency: An overview of the Asian markets. International Journal of Business and Management 5 (6): 56-73.

Birtchell, T. 2011. Jugaad as systematic risk and disruptive innovation in India. Contemporary South Asia 19 (4): 357-372.

Biswas, N. B. 1998. Economics and ethics in an Indian society: A reflective analysis. International Journal of Social Economics 25 (6/7/8): 1064-1072.

Brown, M. T. 2006. Corporate integrity and public interest: A relational approach to business ethics and leadership. Journal of Business Ethics 66 (1): 11-18.

Bussel, J. L. 2010. Why get technical? Corruption and the politics of public service reform in the Indian states. Comparative Political Studies 43 (10): 1230-1257.

Carroll, S. J. and M.J.Gannon. 1997. Sage Series in Business Ethics: Ethical dimensions of international management. Thousand Oaks, CA: SAGE Publications, Inc., doi: 10.4135/9781483327778

Chakraborty, S. K. 1995. Ethics in Management. Vedantic Perspectives. Oxford University Press. 
Chakraborty, S. K. 1997. Business ethics in India. Journal of Business Ethics 16 (14): 15291538.

Christie, P. M. J., I. G. Kwon, P. A. Stoeberl, and R. Baumhart. 2003. A cross-cultural comparison of ethical attitudes of business managers: India, Korea and the United States. Journal of Business Ethics 46 (3): 263-287.

Correia, T.S. and W. G. L. Lucena (2020). Board of directors and code of business ethics of Brazilian Companies. RAUSP Management Journal 55(2): 263-279

Cortina, J. M. 1993. What is coefficient alpha? An examination of theory and applications. Journal of Applied Psychology 78 (1): 98.

Das, D. K. 2006. The Chinese and Indian economies: comparing the comparables. Journal of Chinese Economic and Business Studies 4 (1): 77-89.

Davis, J. 2004. Corruption in public service delivery: Experience from South Asia's water and sanitation sector. World Development 32 (1): 53-71.

Deshpande, S. P., E. George, and J. Joseph. 2000. Ethical climate and managerial success in Russian organizations. Journal of Business Ethics 23: 211-217.

Deshpande, S. P., J. Joseph, and X. Shu. 2011. Ethical climate and managerial success in China. Journal of Business Ethics 99: 527-534.

Diacon, S. R. and C. T. Ennew. 1996. Can business ethics enhance corporate governance? Evidence from a survey of UK insurance executives. Joumal of Business Etbics 15 (6): 623-634.

Erondu, E. A., A. Sharland, and J. O. Okpara. 2004. Corporate ethics in Nigeria: A test of the concept of an ethical climate. Journal of Business Ethics 51 (4): 349-357.

Ferrell, O. C. 2005. Business Ethics, 6th Edition. Boston: Houghton Mifflin.

Fikkert, B. and H. Rana. 1998. Returns to scale in a highly regulated economy: Evidence from Indian firms. Journal of Development Economics 56 (1): 51-79.

Fontrodona, Joan, J. E. Ricart, and P. Berrone. 2018. Ethical challenges in strategic management. 19th IESE International Symposium on Ethics, Business and Society. Journal of Business Ethics. 152: 887-898.

Garegnani, G. M., E. P. Merlotti, and A. Russo. 2015. Scoring firms' codes of ethics: An exploratory study of quality drivers. Journal of Business Ethics 126 (4): 241-557.

Ghosh. S. K. 2021. Swachh Bharat is a recipe for India's growth: India improved a sharp 108 positions in Bribery Index for 6 years ended. Ecowrap, March 22, Issue 82. 
Hawkins, T. G., M. J. Gravier, and H. P. Powley. 2011. Public versus private sector procurement ethics and strategy: What each sector can learn from the other. Marketing Department Journal Articles. Bryant University. 28: 1-46.

Heston, A. and V. Kumar. 2008. Institutional flaws and corruption incentives in India. The Journal of Development Studies 44 (9): 1243-1261.

Hoff, K. and P. Pandey. 2005. Opportunity is not everything. Economics of Transition 13 (3): 445-472.

Hur, W., S. Kang, and M. Kim. 2015. The moderating role of Hofsted's cultural dimensions in the customer-brand relationship in China and India. Cross Cultural Management: An International Journal 22(3): 487-508.

Kanagasabapathi, P. 2007. Ethics and values in Indian economy and business. International Journal of Social Economics 34 (9): 577-585.

Kersley, R, E. Klerk, A. Boussie, B. S. Longworth, J. A. Natzkoff, and D. Ramji. 2019. The CS gender 3000 in 2019: The changing face of companies. Credit Suisse Research Institute. Available at https://www.credit-suisse.com/about-usnews/en/articles/news-and-expertise/cs-gender-3000-report-2019-201910.html Assessed December 25, 2020.

Khandwalla, P. N. 2002. Effective organisational response by corporates to India's liberalisation and globalisation. Asia Pacific Journal of Management 19 (2/3): 423-448.

Krishna, A. 2003. What is happening to caste? A view from some North Indian Villages. The Journal of Asian Studies 62 (4): 1171-1193.

LeFebvre, R. 2011. Cross-cultural comparison of business ethics in the US and India: a study of business codes of conduct. Journal of Emerging Knowledge on Emerging Markets 3: 391-409.

Local Circles. 2019. India Corruption Survey 2019: Report. (https://www.localcircles.com/a/press/page/india-corruption-survey2019\# executive-summary).

Longenecker, J. G., C. W. Moore, J. W. Petty, L. E. Palich, and J. A. McKinnery, J. A. 2006. Ethical attitudes in small business and large corporations: Theory and empirical findings from a tracking study spanning three decades. Journal of Small Business Management 44 (2): 167-183.

Majumdar, S. K. 2004. The hidden hand and the license Raj to an evaluation of the relationship between age and the growth of firms in India. Journal of Business Venturing 19 (1): 107-125. 
Mulla, Z. R. 2003. Corporates in India cannot afford to be ethical. Management and Labour Studies 28 (1): 49-53.

Newell, S. J., W. Wu, D. Leingpibul, and Y. Jiang. 2016. The importance of corporate and salesperson expertise and trust in building loyal business-to-business relationships in China. Journal of Personal Selling \& Sales Management 36(2): 160-173.

Office of the United States Trade Representative 2020 ustr.gov/countries-regions/southcentral-Asia/India.

Oumlil, A. B. and J. L. Balloun. 2009. Ethical decision-making differences between American and Moroccan managers. Journal of Business Ethics 84 (4): 457-478.

Paik, Y., J. M. Lee and S. P. Yong. 2019. Convergence in international business ethics? A comparative study of ethical philosophies, thinking style, and ethical decisionmaking between US and Korean managers. Journal of Business Ethics. 156: 839-855

Raja, J. and A. S. Kumar. 2007-2008. SME Entrepreneurship, firm performance, and corporate governance practices in Indian service firms. Journal of Services Research 7 (2): 99-113.

Rajeev, P. 2007. Wisdom from ancient Indian philosophy for the corporate world. International Management Review 3 (1): 72-81.

Ramesh, R. S. and P. Goel. 2014. Attitude and perception of public towards business ethics: Evidence from select seven states of India. Indian Journal of Commerce and Management Studies 5 (1): 47-53.

Remisova, A., A. Lasakaova, and Z. Kirchmayer. 2019. Influences of formal ethics program components on managerial ethical behavior. Journal of Business Ethics 160: 151-166.

Riley, P. and R. K. Roy. 2016. Corruption and anticorruption: The case of India. Journal of Developing Societies 32 (1): 73-99

Ritterbush, E. 2020. How to hire ethical employees. Blog. www.ddiworld.com/blog/howto-hire-ethical-employees. February 12.

Robertson, C. J., W. F. Crittenden, M. K. Brady, and J. James, J. 2002. Situational ethics across borders: A multicultural examination. Journal of Business Ethics 38 (4): 327 338.

Rooplekha, K., and S. Damodar. 2004. A scale to assess ethical leadership of Indian private and public sector managers. Journal of Business Ethics 49(1): 13-26.

Ruhe, J. 2008. Teaching ethics in international business courses: The impact of religion. Journal of Teachings in International Business 19 (4): 362388. 
Sardozoska, E. G. and T. L. Tang. 2009. Testing a model of behavioral intentions in the Republic of Macedonia: Differences between the private and the public sectors. Journal of Business Ethics 87: 495-517.

Saran, A. and C. Guo. 2005. Competing in the global market place: the case of India and China. Business Horizons 48 (2): 135-142.

Schminke, M. 2001. Considering the business in business ethics: An exploratory study of the influence of organizational size and structure on individual ethical predispositions. Journal of Business Ethics 30 (4): 375-390.

Seshadri, D. V. R., A. Raghavan, A, and S. Hegde. 2007. Business ethics: The next frontier for globalizing Indian companies. Vikalpa 32 (3): 61-80.

Silver, C. 2020. The top 20 economies in the world: Ranking the richest countries in the world. Investopedia, www.investopedia.com/insights/worlds-top-economies/

Sims, R. L. and A. E. Gegez. 2004. Attitudes towards business ethics: A five nation comparative study. Journal of Business Ethics 50 (3): 253-265.

Singh, J.B., G. Wood, M. Callaghan, G. Svensson, and S. Andersson. 2018. Operationalizing business ethics in organizations: The views of executives in Australia, Canada and Sweden. European Business Review 30 (4):494-510.

Svensson, G., G. Wood, and M. Callaghan. 2009. Cross-sector organizational engagement with ethics: A comparison between private sector companies and public sector entities of Sweden. Corporate Governance 9 (3): 283-297.

Trace International. 2020. https://www.traceinternational.org/trace-matrix.

Tsalikis, J. and W. Lassar. 2009. Measuring consumer perceptions of business ethical behavior in two Muslim countries. Journal of Business Ethics 89 (1): 91-98.

Tsalikis, J., B. Seaton, and T. Li. 2008. The international business ethics index: Asian emerging economies. Journal of Business Ethics 80 (4): 643-651.

Vaidya, R. 2019. Corruption, re-corruption and what transpires in between: The case of a government officer in India. Journal of Business Ethics 156 (3): 605-620.

Valentine, S. R. and T. L. Rittenburg. 2004. Spanish and American business professionals' ethical evaluations in global situations. Journal of Business Ethics 51 (1): 1-14.

Venkataraman, R. 2018. An unethical place: Waning ethics in India's private sector. indianexpress.com/article/opinion/columns/an-unethical-place-businesscorruption-pri9vate-sector-informal-transparency-5057835. February 10, 2018 
Vernon, R., G. Williams, S. Corbridge, S., and M. Srivastava. 2006. Decentralized corruption or corrupt decentralization? Community monitoring of poverty-alleviation schemes in eastern India. World Development 34 (11): 1922-1941.

Xiaobo, W. (2016). Where are China's business ethics? Sixth Tone. www.sixthtone.com/news/1140/where-are-chinas-business-ethics\%3F. August 2, 2016 